\title{
The Length-Weight, Length-Length Relationship and Condition Factor of Angora Loach, Oxynoemacheilus angorae (Steindachner, 1897) Inhabiting Kılıçözü Stream in Kızılırmak River Basin (Central Anatolia- Turkey)
}

\author{
Okan Yazıcıoğlü ${ }^{*}$, Ramazan Yazıcı ${ }^{2}$ \\ ${ }^{1}$ Organic Farming Program, Botanic and Animal Production Department, Technical Vocational Schools of Higher Education, Ahi Evran \\ University, 40100 Kirşehir, Turkey \\ ${ }^{2}$ Laboratory and Veterinary Health Department, Çiçekdağ Technical Vocational Schools of Higher Education, Ahi Evran University, 40700 \\ Kırşehir, Turkey

\begin{tabular}{l}
\hline A R T I C L E I N F O \\
\hline Article history: \\
Received 05 September 2016 \\
Accepted 03 November 2016 \\
Available online, ISSN: 2148-127X \\
\hline Keywords: \\
Angora loach \\
Length-weight relationship \\
Condition factor \\
Kizilırmak river \\
Turkey
\end{tabular}
\begin{abstract}
A B S T R A C T
In this study, length-weight relationship (LWR), length- length relationship (LLR) and condition factor (K) of Angora loach, Oxynoemacheilus angorae were determined. A total of 103 specimens were sampled from Kılıçözü Stream in 2014. The length and weight of specimens were ranged $3.5-9.8 \mathrm{~cm}$ and $0.38-6.58 \mathrm{~g}$, respectively. Lengthweight relationships for female, male and all samples were found as $\mathrm{W}=0.01056$.TL $^{2.896}$ $\left(r^{2}=0.923\right), W=0.00963 . T L^{2.940}\left(r^{2}=0.978\right)$ and $W=0.00987 . T^{2.929}\left(r^{2}=0.963\right)$, respectively. LWRs indicated an isometric growth in female, male and all samples. The values of Fulton's condition factor $(\mathrm{K})$ ranged from 0.699 to 1.246 for females and from 0.654 to 1.072 for males. All length-length relationships were statistically significant.
\end{abstract}

"Corresponding Author:

E-mail: oknyzcoglu@gmail.com

\section{Introduction}

Angorae loach, Oxynoemacheilus angorae (Steindachner, 1897) is a teleost fish which inhabiting in the Middle East Asia. Angora loach described as least concern in The IUCN Red List of Threatened Species and declared that this situation will worsen in the future. It inhabits a wide range of habitats from streams and shores of large rivers to muddy lakes with dense vegetation. This species spawns commonly first time at 1 year. Angora loach feeds on benthic invertebrates (Freyhof, 2014).

Relationship between length and weight varies among fish species according to their body shape and condition of fishes (Schneider et al., 2000). It is an important fishery management tool (Bolger and Connoly, 1989). These relationships also permit the calculation of condition indexes and let for comparisons of species growth orbit between sexes, different seasons, and regions (Froese, 2006). Also it is important for conservation of fish species (Kamaruddin et al., 2011). Fulton's condition factor $(\mathrm{K})$ is commonly utilized in fisheries and fish biology researches (Froese, 2006). Condition factor indicate differences according to sexual maturity, availability of food sources, age and sex of some species (Anibeze, 2000). Total length (TL) and fork length (FL) is usually utilized in studies of fish growth, whereas standard length (SL) is mainly used in systematic studies (Arslan et al., 2004). In this situation, there are difficult for studies to be compared with each other and to interpret the results (Yazıcı et al., 2015). Therefore, length-length transformations in fish are useful for comparative studies using different length measures (Y1lmaz et al., 2010; Tsagarakis et al., 2015). There are a few investigations on the length-weight, length-length relationship and condition factor of Angora loach from Kizilırmak River basin (Birecikligil et al., 2016). Also, a research on karyotype of Angora loach was conducted at inland waters in Kırşehir (Gaffaroğlu et al., 2014).

In this paper, we report that length-weight, lengthlength relationships and condition factor of Angora loach inhabiting Kılıçözü Stream at Kızılırmak River basin.

\section{Materials and methods}

Study Area

Kılıçözü Stream is located northern side of Baran mount in Kırşehir (Turkey-Central Anatolia). It is mix to Kizılirmak River and flow North-south direction. Length of this stream is $80 \mathrm{~km}$. İğdeliöz, Kılıçözü, Güzler irrigation regulators and Çoğun dam lake were built on Kılıçözü Stream. The water level of stream reduces in summers. The average flow rate of the stream is 34.3 $\mathrm{hm}^{3} /$ year (Anonymous, 2011). 


\section{Sample Size and Data Collection}

A total of 103 O. angorae were obtained from Kılıçözü Stream. Catching of fish samples were conducted by using electrofisher in October 2014. After the collection of the fish samples were transported to the research laboratory. The total length (TL), fork length (FL), and standard length (SL) of each specimen was measured to the nearest $1 \mathrm{~mm}$ and their weight was determined using digital balance with precision of $0.01 \mathrm{~g}$. Sex determination was performed by macroscopic examination of gonads. The chi-squared test was carried out on the observed sex ratios to show whether the proportions deviated significantly from the expected 1: 1 ratio (Zar, 1999). The length-weight relationship was calculated via the formula $\mathrm{W}=a x L^{b}$, where $\mathrm{W}$ is the body weight $(\mathrm{g}), \mathrm{L}$ is the total length $(\mathrm{cm}), a$ is the intercept, and $b$ is the slope (Bagenal and Tesch, 1978). The parameters $a$ and $b$ of length-weight relationship were estimated by linear regression of the transformed equation: $\log \mathrm{W}=\log a+b \log \mathrm{L}$. The determination coefficient $\left(r^{2}\right)$ was used as an indicator of the quality of the linear regression. Whether the growth of fish was isometric $(b=3)$ or allometric $(b>3, b<3)$ was estimated by the student's t-test. Analysis of covariance (ANCOVA) was used to test difference of the $b$ values of length-weight relationship between sexes (Zar, 1999). The Fulton's condition factor was computed using the formula $\mathrm{K}=100 \mathrm{~W} \mathrm{~L}^{-3}$, where $\mathrm{K}$ is the Fulton's condition factor, $\mathrm{W}$ is the body weight $(\mathrm{g})$, and $\mathrm{L}$ is the total length $(\mathrm{cm})$ (Ricker, 1975). Differences between K values of females and males were tested using the student's t-test (Zar, 1999). All length-length relationships were established using linear regression analysis. Relationships between TL \& FL, FL \& SL, and SL \& TL were estimated separately according to females, males and all samples. All statistical analyses were considered significant at $\mathrm{P}<0.05$.

\section{Results}

\section{Sex, Length and Weight Distribution}

During the study period, a total of 103 individuals were captured. $63(61.16 \%)$ were females and 40 $(38.84 \%)$ were males. Overall sex ratio of females to males was 1.0:0.63, which did deviate from $1: 1 \quad\left(x^{2}=\right.$ $5.136, \mathrm{P}<0.05)$. The total lengths and body weights of all samples varied as $3.5-9.8 \mathrm{~cm}($ mean $=7.354, \mathrm{SD}=1.185)$ and $0.38-6.58 \mathrm{~g}($ mean $=3.647, \mathrm{SD}=1.324)$, respectively (Table 1).

\section{Length-Weight Relationships}

Length-weight relationships showed that high compatibility between length and weight of males, females and all individuals $\left(\mathrm{P}<0.001, r^{2}>0.92\right)$. Totally, parameters $b$ of LWR was computed as 2.940 for males, 2.896 for females and 2.929 for all samples (Table 1). The variations in $b$ values from 3 were not statistically significant and indicated an isometric growth for males $(\mathrm{t}$ $=-0.84, \mathrm{P}>0.05)$, females $(\mathrm{t}=-0.98, \mathrm{P}>0.05)$, and the overall population $(\mathrm{t}=-1.24, \mathrm{P}>0.05)$. No significant difference was observed in slopes of LWR of females and males (ANCOVA, $\mathrm{F}=0.12, \mathrm{P}>0.05$ ).

\section{Condition Factor}

The average value of Fulton's condition factor $(\mathrm{K})$ was calculated as 0.864 for males, 0.863 for females, and 0.863 for all samples (Table 2). There was no significant difference in mean $\mathrm{K}$ values between sexes (t-test, $\mathrm{P}>0.05)$. The higher $\mathrm{K}$ values of females and males were obtained in the 6.5-7.9 $\mathrm{cm}(\mathrm{K}=0.87)$ and 5.0-6.4 $\mathrm{cm}(\mathrm{K}=$ 0.922 ) length group, respectively. Mean $\mathrm{K}$ values of females increased with length groups, whereas the mean $\mathrm{K}$ values decreased with length groups in males (Figure $1)$.

\section{Length-Length Relationships}

All length- length relationship parameters of $O$. angorae were shown in Table 3. The determined $r^{2}$ values for all LLRs of females, males and all specimens were greater than 0.972 and highly significant $(\mathrm{P}<0.001)$.

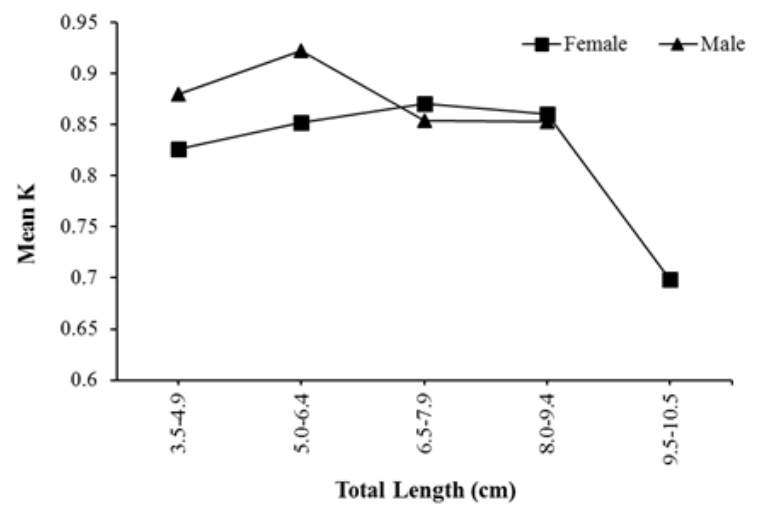

Figure 1 Mean condition factor $(\mathrm{K})$ per total length class for female and male of Angora loach from Kilıçözü Stream, Turkey

Table 1 Descriptive statistics and estimated parameters of length-weight relationship (LWR) of Angora loach from Kılıçözü Stream, Turkey.

\begin{tabular}{l|lcccccccc}
\hline \multirow{2}{*}{ Sex } & \multirow{2}{*}{$\mathrm{n}$} & \multicolumn{2}{c}{ Total Length $(\mathrm{cm})$} & \multicolumn{2}{c}{ Weight $(\mathrm{g})$} & \multicolumn{4}{c}{ Parameters of LWR } \\
\cline { 3 - 10 } & & Min & Max & Min & Max & $\mathrm{a}$ & $\mathrm{b}$ & $95 \%$ CI of b & $\mathrm{r}^{2}$ \\
\hline Male & 40 & 3.5 & 8.9 & 0.38 & 6.06 & 0.0096 & 2.940 & $2.795-3.085$ & 0.978 \\
Female & 63 & 3.9 & 9.8 & 0.49 & 6.58 & 0.0105 & 2.896 & $2.681-3.109$ & 0.923 \\
All & 103 & 3.5 & 9.8 & 0.38 & 6.58 & 0.0098 & 2.929 & $2.815-3.042$ & 0.963 \\
\hline
\end{tabular}

n: sample size, $a$ and $b$ : parameters of LWRs, Min: minimum, Max: maximum, $r^{2}$ : coefficient of determination 
Table 2 Descriptive statistics of condition factor of Angora loach from K1liçözü Stream, Turkey.

\begin{tabular}{l|cccccc}
\hline \multicolumn{1}{c|}{ Sex } & $\mathrm{n}$ & Mean K & SE & SD & Min & Max \\
\hline Male & 40 & 0.864 & 0.0158 & 0.0998 & 0.654 & 1.072 \\
Female & 63 & 0.863 & 0.0122 & 0.0969 & 0.699 & 1.246 \\
All & 103 & 0.863 & 0.0096 & 0.0975 & 0.654 & 1.246 \\
\hline
\end{tabular}

n: sample size, SE: standard errors, SD: standard deviation, Min: minimum, Max: Maximum

Table 3 Length-length relation parameters between total, fork and standard length of Angora loach from Kılıçözü Stream, Turkey.

\begin{tabular}{|c|c|c|c|c|c|}
\hline Sex & $\mathrm{n}$ & Equation & $\mathrm{a}$ & $\mathrm{b}$ & $\mathrm{r}^{2}$ \\
\hline \multirow{3}{*}{ Male } & \multirow{3}{*}{40} & $\mathrm{TL}=\mathrm{a}+\mathrm{bFL}$ & 0.092 & 1.01 & 0.999 \\
\hline & & $\mathrm{FL}=\mathrm{a}+\mathrm{bSL}$ & 0.150 & 1.13 & 0.992 \\
\hline & & $\mathrm{SL}=\mathrm{a}+\mathrm{bTL}$ & -0.165 & 0.867 & 0.993 \\
\hline \multirow{3}{*}{ Female } & \multirow{3}{*}{63} & $\mathrm{TL}=\mathrm{a}+\mathrm{bFL}$ & -0.139 & 1.05 & 0.992 \\
\hline & & $\mathrm{FL}=\mathrm{a}+\mathrm{bSL}$ & 0.325 & 1.11 & 0.975 \\
\hline & & $\mathrm{SL}=\mathrm{a}+\mathrm{bTL}$ & 0.022 & 0.837 & 0.972 \\
\hline \multirow{3}{*}{ All } & \multirow{3}{*}{103} & $\mathrm{TL}=\mathrm{a}+\mathrm{bFL}$ & 0.022 & 1.02 & 0.997 \\
\hline & & $\mathrm{FL}=\mathrm{a}+\mathrm{bSL}$ & 0.203 & 1.12 & 0.987 \\
\hline & & $\mathrm{SL}=\mathrm{a}+\mathrm{bTL}$ & -0.102 & 0.855 & 0.986 \\
\hline
\end{tabular}

n: sample size, $a$ and $b$ : parameters of LLRs

Table 4 The total lengths and weights for Angora loach populations in different localities.

\begin{tabular}{l|cccc}
\hline \multicolumn{1}{c|}{ Locality } & Sex & TL (Min-Max) & W (Min-Max) & Reference \\
\hline Jajroud River & All & $3.8-7.6 \mathrm{~cm}$ & $0.53-4.21 \mathrm{~g}$ & Golzarianpour et al., 2011 \\
Balıklı Stream & All & $4.7-7.3 \mathrm{~cm}$ & $0.86-3.56 \mathrm{~g}$ & Gaygusuz et al., 2013 \\
Karabogaz Creek & All & $4.4-8.3 \mathrm{~cm}$ & $0.80-6.60 \mathrm{~g}$ & Erk'akan et al., 2014 \\
Sirwan River & All & $4.3-8.2 \mathrm{~cm}$ & - & Hasankhani et al., 2014 \\
Kizılırmak River Basin $_{\text {Kilıçözü Stream }}$ & All & $2.8-8.6 \mathrm{~cm}$ & $0.22-6.18 \mathrm{~g}$ & Birecikligil et al., 2016 \\
\hline
\end{tabular}

Table 5 The parameters of length-weight relation for Angora loach from different habitats.

\begin{tabular}{l|ccccc}
\hline \multicolumn{1}{c|}{ Locality } & Sex & $\mathrm{a}$ & $\mathrm{b}$ & $\mathrm{r}^{2}$ & Reference \\
\hline Jajroud River & All & 0.008 & 3.01 & 0.98 & Golzarianpour et al., 2011 \\
Balıklı Stream & All & 0.006 & 3.237 & 0.88 & Gaygusuz et al., 2013 \\
Karabogaz Creek & All & 0.0062 & 3.228 & 0.92 & Erk'akan et al., 2014 \\
Sirwan River & All & 0.011 & 2.81 & 0.96 & Hasankhani et al., 2014 \\
Kizılırmak River Basin & All & 0.008 & 3.102 & 0.94 & Birecikligil et al., 2016 \\
\hline \multirow{3}{*}{ Kilıçözü Stream } & Male & 0.0096 & 2.940 & 0.98 & This study \\
& Female & 0.0106 & 2.896 & 0.92 & 0.96 \\
\hline
\end{tabular}

\section{Discussion}

The sex ratio of Angora loach in the Kılıçözü Stream was 1.0: 0.63. In other words, females dominated in this population. This result concurs with different researches, which including information about other fish species (Kostrzewa et al., 2003; Yazıcıoğlu et al., 2013; Saylar and Y1lmaz, 2014; Jamali et al., 2016).

Total lengths and weights values were similar to different habitats (Table 4). However, there are some differences. The number of samples, sampling time and ecological conditions of habitats may have led to these differences.

The strong relationships between total length and weight were observed $\left(\mathrm{P}<0.001, r^{2}>0.96\right)$. The slope $(b)$ of length-weight relationships range from 2 to 4 in fish (Bagenal and Tesch, 1978). Calculated $b$ parameters of length-weight relationship for females, males, and all fish were close to 3 , which is isometric growth indicator.
Calculated $b$ parameter for all samples was lower than conclusions of studies at other habitats. However, it was consistent with data from the Sirwan River (Table 5). Inconsistencies in comparing other habitats may be resulted from number of samples, length and weight distributions, used fishing methods, feeding capacity, food abundance and ecological conditions of habitats. Also, Bagenal and Tesch (1978) reported that lengthweight relationship in fish is not stable and it changes depending on feeding ratio, gonad development, food availability and reproduction period.

Mean K value of this species was calculated as 0.863 for females, 0.864 for males, and 0.863 for all samples. Birecikligil et al. (2016) reported that average $\mathrm{K}$ value of $O$. angorae in Kizilırmak river basin was 0.94. This result is very close to our finding. 
Consequently, this study indicates structural data of population of Angora loach. This species showed good development in Kilıçözü Stream when compared to other habitats. The data of this study are very important. Because $O$. angorae describe as least concern in The IUCN Red List of Threatened Species. Results obtained from this study may be useful in the future to obtain information about population dynamic of $O$. angorae.

\section{Acknowledgements}

This work was funded by the Ahi Evran University Scientific Research Projects Coordination Unit (Project No: TBY. E2.16.003).

\section{References}

Anibeze CIP. 2000. Length-weight relationship and relative condition of Heterobranchus longifilis (Valenciennes) from Idodo River, Nigeria. Naga, The ICLARM Quarterly., 23(2): 34-35.

Anonymous. 2011. Kirsehir Environmental Status Report. Kırşehir Governor.

Arslan M, Yıldırım A, Bektaş S. 2004. Length-weight relationship of brown trout, Salmo trutta L., inhabiting Kan stream, Coruh Basin, north-eastern Turkey. Turkish Journal of Fisheries and Aquatic Sciences., 4(1): 45-48.

Bagenal TB, Tesch FW. 1978. Age and growth. In: Bagenal TB. (ed.). Methods for Assessment of Fish Production in Freshwaters. Oxford: UK. Blackwell Scientific Publications. pp. 101-136.

Birecikligil SS, Çiçek E, Öztürk S, Seçer B, Celepoğlu Y. 2016. Length-length, length-weight relationship and condition factor of fishes in Nevşehir Province, Kizılırmak River Basin (Turkey). Acta Biologica Turcica., 29(3): 72-77.

Bolger T, Connolly PL.1989. The selection of suitable indices for the measurement and analysis of fish condition. Journal of Fish Biology., 34(2): 171-182.

Erk'akan F, Innal D, Özdemir F. 2014. Length-weight relationships for some endemic stone and spine loach species in Anatolia. Journal of Applied Ichthyology., 30(1): 244-245.

Freyhof J. 2014. Oxynoemacheilus angorae. The IUCN Red List of Threatened Species 2014: e.T14493A19849461. http://dx.doi.org/10.2305/IUCN.UK.2014 -1.RLTS.T14493A19849461.

Froese R. 2006. Cube law, condition factor and weight-length relationships: history, meta-analysis and recommendations. Journal of applied ichthyology., 22(4): 241253.

Gaffaroğlu M, Ünal S, Karasu Ayata M. 2014. Oxynoemacheilus angorae (Steindachner, 1897) (Teleostei: Nemacheilidae)'nin Karyotip Özellikleri. 22. Ulusal Biyoloji Kongresi. Eskişehir, 23-27 June 2014. ESOGÜ, 1342.

Gaygusuz Ö, Aydın H, Emiroğlu Ö, Top N, Dorak Z, Gürsoy Gaygusuz Ç, Başkurt S, Tarkan AS. 2013. Length-weight relationships of freshwater fishes from the western part of Anatolia, Turkey. Journal of Applied Ichthyology., 29: 285287.
Golzarianpour K, Abdoli A, Kiabi BH. 2011. Length-weight relationships for nine nemacheilian loaches (Teleostei: Nemacheilidae) from Iran. Journal of Applied Ichthyology., 27: 1411-1412.

Hasankhani M, Keivany Y, Daliri M, Pouladi M, Soofiani NM. 2014. Length-weight and length-length relationships of four species (Barbus lacerta Heckel, 1843), Oxynoemacheilus angorae (Steindachner, 1897), Squalius lepidus (Heckel, 1843) and Pseudorasbora parva (Temminck \& Schlegel, 1846) from the Sirwan River (western Iran). Journal of Applied Ichthyology., 30(1): 206-207.

Jamali H, Patimar R, Farhadi M, Daraei V. 2016. Age, growth and reproduction of Paracobitis malapterura (Teleostei: Nemacheilidae) from Qom River, Iran. Iranian Journal of Ichthyology., 3(1): 43-52.

Kamaruddin IS. Mustafa-Kamal AS, Christianus A, Daud SK, Amin SMN, Yu-Abit L. 2011. Length-weight Relationship and condition factor of three dominant species from the lake Tasik Kenyir, Terengganu. Malaysia.Journal of Fisheries and Aquatic Science., 6(7): 852.

Kostrzewa J, Przybylski M, Marszał L, Valladolid M. 2003. Growth and reproductive biology of loaches Cobitis sp. in Lake Lucień, Poland. Folia Biologica (Kraków).51(5):179-182.

Ricker WE. 1975. Computation and interpretation of biological statistics of fish populations. Ottawa: Canada. Bulletin of the Fisheries Research Board of Canada.

Saylar Ö, Y1lmaz S. 2014. Some of the biological features of the brond-snout (Chondrostoma regium Heckel, 1843) living in Lake Ladik (Samsun, Turkey). Ankara Univ Vet Fak Derg., 61: 141-146.

Schneider JC, Laarman PW, Gowing H. 2000. Length-weight relationships. In Schneider JC Ed. Manual of fisheries survey methods II: with periodic updates. Ann Arbor: Michigan Department of Natural Resources, Fisheries Special Report 25.

Tsagarakis K, Başusta A, Başusta N, Biandolino F, Bostanci D, Buz K, Djodjo Z, Dulčić J, Gökoğlu M, Gücü AC, Machias A, Maravelias CD, Özvarol Y, Polat N, Prato E, Vasilakopoulos P, Yedier S. 2015. New Fisheries-related data from the Mediterranean Sea (October 2015). Mediterranean Marine Science., 16(3): 703-713.

Yazıcı R, Yılmaz S, Yazıcıoğlu O, Polat N. 2015. Population structure and growth of rudd Scardinius erythrophthalmus (L., 1758) from a eutrophic lake in northern Anatolia. Croatian Journal of Fisheries., 73(3): 94-102.

Yazıcıoğlu O, Yılmaz S, Yazıcı R, Polat N. 2013. Condition Factor, Length-Weight and Length-Length Relationships of Prussian Carp, Carassius gibelio (Bloch, 1782) Inhabiting Lake Ladik, Samsun, Turkey. The Black Sea Journal of Sciences., 3(9):7280.

Yılmaz S, Yazıcıŏlu O, Y1lmaz M, Polat N. 2010. Length-Weight and Length-Length Relationships, and Seasonal Conditon Factors of Cyprinus carpio L., 1758 and Tinca tinca (L., 1758) Inhabiting Hirfanlı Dam Lake. SDU Journal of Science (EJournal)., 5(2):154-162.

Zar JH. 1999. Biostatistical Analysis. 4th edition., New Jersey: USA. Prentice Hall. 